\title{
Critical success factors in information technology projects
}

\author{
Ayesha Fayaz ${ }^{\mathrm{a}}$, Yasir Kamal ${ }^{\mathrm{b}}$, Saif ul Amin ${ }^{\mathrm{a}^{*}}$ and Sammandar Khan ${ }^{\mathrm{a}}$
}

${ }^{a}$ Department of Management Sciences, COMSATS Institute of Information Technology (CIIT), Islamabad, Pakistan ${ }^{b}$ Department of Management Sciences, Institute of Management Sciences (IMSciences), Peshawar, Pakistan

CHRON I CLE A B S TRACT

Article history:

Received: October 1, 2016

Received in revised format: No-

vember 16, 2016

Accepted: November 29, 2016

Available online:

November 30, 2016

Keywords:

Project success

Critical success factors

Project management

Project failure

IT Project

\begin{abstract}
The purpose of this study is to determine the critical success factors (CSF) of IT projects in Pakistan. The identified factors cannot only be functional to exact type IT projects but also to all types of IT projects, their success directly affects the achievement of whole organization. The proposed study of this paper has determined 15 factors influencing the most on the success of IT projects through multiple regression analysis. The survey has disclosed that many CSFs were found related to IT projects but these 15 factors are also the backbone of IT projects. The research results obtained clearly indicated that the Leadership Qualities played a significant role in obtaining Top Management support in order to access to resources however, the Leadership Qualities did not play any role on the trained and capable Project Team Members. Besides, it is undoubtedly defined effective communication of the project was established to be influential on the conclusion and contributing factor towards the Success of IT projects in Pakistan. Top Management Support as a whole was not found to play a key role in the IT Project Success.
\end{abstract}

C) 2017 Growing Science Ltd. All rights reserved.

\section{Introduction}

In the 1980s the word CSF came under research work, in order to find out why some organizations had been more successful than others. The term Critical Success Factors (CSF) is defined as "those things that must be done if a company is to be successful" and it is quantifiable and controllable (Ingram et al., 2000). The dependency on IT has increased manifolds nowadays that depends on information technology (IT) projects success.

Information technologies are important tools that carry high adaptation rate in highly complicated settings. IT is one of the key factors educating organizations performance and output. The acceptance of new technology in developed and non-developing countries have happened also with different other obstacles as well as deficiency of organizational coordination, clashes, lack of higher management support and understanding of technology. Individuals play an important role in process of technology adoption. The success of IT technology depends on user's adaptation. For organization development 
when investing in IT, project must be calculated in terms of its capability, timely delivery, cost, avoiding risks and quality (Amin et al., 2016).

Today, IT industry in Pakistan largely uses different kinds of projects for the general business. In Pakistan, very few IT organizations are product based. People, employees and/or team members or team heads within the projects consider technical work as the central focal point of the project and therefore pay no attention to project management. Because of the fast growth of information technology trade, nowadays people have vastly acknowledged the meaning of execution of IT projects.

Management of IT project often faces issues like fast technology upgradation, human being movement and environmental modifications. Organizational and management process issues encompass those factors that affect control over planning, procurement, and implementation of information technologies. Some of these issues include: Management process issues (express to the practical operations of organizations, like budgeting, employees, and general management), Organizational issues (organizational culture, change, behavior and Organizational size) Project size (that might affect relationships between critical success factors and project performance), leadership issues (those areas which need the communication and path of the organization executive such as different units coordination and administrative support), Technical systems issues (hardware and software deliberations of information technologies) and personnel issues (employee expertise levels, staffing levels, and conflict to change). The IT projects success is important because the dependency on IT has increased manifolds nowadays. Top management support and management, training, clear vision and IT system goals and interdepartmental communication are the most often quoted CSFs in the implementation of IT projects success. Reliable empirical data are missing for the relations between project performance, information technology, and critical success factors. Combining methods and ideology project management to IT through accomplishment projects of IT is vital in support of the achievement of projects of Information Technology (Dolan, 2005). Information Technology project's complication and high insecurity may act as CSFs of IT project to be examined from the various points of view. Pakistan has plenty of skillful human resource to work. Being the highly populated country with $2.1 \%$ rate of population Pakistan has the manpower in all fields. But with the countless intervention from management side in organizations' HR policies, the organizations however sometimes feel problems to employ brilliant people (Khilji, 2001). Many projects in Pakistan are unsuccessful due to deficiency of expert employees in their particular field and the same case is with IT projects. Research in the banking industry has shown by Anandarajan et al. (2002) and recognized the basic issues affecting IT norm these features are customer view of originations', firms, society, some sort of contact networks used to the verbose knowledge of the improvement and numerous management factors.

\section{Literature review}

In the majority of the IT projects, strict time and cost overruns have been instituted to be a common case. There are different IT projects found to be lying behind the time frame and also crossing the approved budget. In the perspective of IT Projects, it is essential that the organizations must have to identify key critical success factors, which should be given exceptional interest for ensuring successful execution of IT projects. The identified factors cannot only be functional to exact type of IT projects but to all types of IT projects (Imtiaz et al., 2013).

Critical success factors determination have enormous practical significances as the concerned authority can make use of these factors to understand the success of any project (Françoise et al., 2009). The success of the whole organizations /project depends directly on the success of CSFs. Some other studies related to the critical success factors on projects explored the three questions that are

- What factors do they illustrate the way to project management success?

- What factors do they lead to a successful project? 
- What factors do they direct to consistently successful projects critical success factors of information Technology project included elements associated with top management necessity for the project and its approval? Increases in IT project success rates related to the project manager's capability to react to difficult situations (Biehl, 2007).

To implement IT projects successfully, management should keep an eye on the implementation growth and provide a clear way of the project. They must be agreeable to permit for a mindset change by accepting that at all levels, including themselves a significant amount of learning must be accomplished (Subba Rao, 2000). Top management support has been always identified as the most significant and crucial success factor in projects implementation (Somers \& Nelson, 2004).

The purpose of project monitoring and controlling is to deliver a thoughtful of the project's growth and also effectively communicating that status (Bourne, 2002). Once weaknesses in the project plan are noticed then necessary and preventative actions are certified to carry the project back into a pattern with the project plan. Time to time monitoring and control is useful in preventing incidents and in providing feedback (Imtiaz et al., 2013). Any variations to the pattern of a deliverable and to the standard elements of the project plan should be made with great discussion to defend an effective project result. Researchers determined that the project manager had some impression on project success, due to the individuality, temporary and originality nature of the projects, however, Project Manager's skill and management abilities make these questions answerable (Turner \& Müller, 2005). Systematic development initiates with requirements which are set by values as an important base and driver for supplementary advance actions. Software development is action vigilantly linked with requirements. To allow development of software systems that gratifies most of the client demands we propose policies for gaining well-organized requirement management infrastructure on software development project. The sponsors or end users must be clear about what they want in the first stage, but as the project progresses through subsequent phases, they might see the need to introduce new or altering requirements (Nasir \& Sahibuddin, 2011). Risk management focuses identification of risks that affects the success of the projects and their proper management. Risk management is also listed as critical success factors in the implementation of IT projects (Victor, Emeka, \& Chukwudi). Proper risk management will shrink not only the probability of an event occurring but also the degree of its impact. The organizational importance and risk of IT projects make it a key for the organization. Good risk management augments the likelihood of a successful project. The success of the project risk management faces some challenges like early identification of risks, systemic analysis and strategic control of the identified risks (Tesch et al., 2007). Some key points that lead to failure of risk management include

- Shortage of resources,

- Complexity of projects,

- Improper initial project definition,

- Downstream design changes etc.(Bannerman, 2008).

The three most important human factors are effective project management skills and methodologies provided by the project manager, top management support and user involvement (Nasir \& Sahibuddin, 2011). User involvement refers to a psychological status of the individual and is defined as the significance and personal relevance of a system to a user (Bhatti, 2005). User involvement in the development of the new product is a new research area, while many types of studies on issues linked to customer/ user involvement have occurred in another discipline. User involvement enhances user satisfaction and acceptance by rising realistic expectations about system capabilities (Pastor \& Casanovas, 2003).

\section{Research methodology}

In this research, IT Project Success is taken as the dependent variable and Management support, leadership, Budget support, Right team, teamwork, effective communication, effective monitoring and controlling, requirement specification, project duration, a clear goal, Project progress schedule, team capability and risk management are taken as independent variables. Data is gathered through questionnaire 
and then analyzed that data. The population base was Software houses, large IT firms educational institutions, Telecom sector and NGOs in Pakistan. IT professionals, Consultants, Managers, computer operators, programmers and other people connected with IT projects in their relevant organizations are the population under the investigation for the above said topic, however, the sample set of 100 respondents was incorporated in the study due to the accessibility and reliability problem. A questionnaire form originally used by (Berntsson-Svensson \& Aurum, 2006) in Sweden and Australia has been utilized. The investigated questionnaire has been conducted in Pakistan where 100 questionnaires were distributed and 40 projects were selected for the same sample. Non-probability (purposive sampling) has been used in this data collection process because the size of the population was quite small. All participants have been selected, randomly.

\section{Analysis and finding}

Table 1 suggests that about $83 \%$ of changes are incorporated by the independent variables into the dependent variable. Adjusted R-Square value suggests the same change up-to-the maximum of 79\%. The value of $F$ Statistics shown in Table 1 is within the acceptable region.

Table 1

Model Summary

\begin{tabular}{ccccccc}
\hline Model & R & R Square & Adjusted R Square & Std. Error of the Estimate & Sig. & F \\
\hline 1 & $.912^{\mathrm{a}}$ & .832 & .793 & .2105 & $.000 \mathrm{a}$ & 21.717 \\
\hline
\end{tabular}

a. Predictors: (Constant), Team Work, Risk Management, Users Involvement, management support, Clear Goals, effective monitoring and control, Right Team, Leadership, Project Duration, Team Capability, Budget Support, Effective Communication, Requirement Specification, Training, Project Progress Schedule

Table 2

Coefficients $^{\mathrm{a}}$

\begin{tabular}{|c|c|c|c|c|c|c|c|c|}
\hline & \multirow[t]{2}{*}{ Model } & \multicolumn{2}{|c|}{$\begin{array}{l}\text { Unstandardized } \\
\text { Coefficients }\end{array}$} & \multirow{2}{*}{$\begin{array}{c}\text { Standardized } \\
\text { Coefficients }\end{array}$} & \multirow[t]{2}{*}{$\mathrm{t}$} & \multirow[t]{2}{*}{ Sig. } & \multicolumn{2}{|c|}{ Collinearity Statistics } \\
\hline & & $\mathrm{B}$ & Std. Error & & & & Tolerance & VIF \\
\hline \multirow[t]{16}{*}{1} & (Constant) & .794 & .244 & & 3.246 & .002 & & \\
\hline & management support & .039 & .059 & .061 & .665 & .509 & .304 & 3.285 \\
\hline & Effective Communication & .077 & .102 & .105 & .754 & .454 & .131 & 7.609 \\
\hline & Training & .105 & .133 & .129 & .793 & .431 & .096 & 10.379 \\
\hline & effective monitoring and control & .014 & .129 & .019 & .111 & .912 & .089 & 11.281 \\
\hline & Leadership & .045 & .133 & .055 & .337 & .737 & .097 & 10.264 \\
\hline & Clear Goals & .050 & .128 & .067 & .394 & .695 & .088 & 11.394 \\
\hline & Requirement Specification & .013 & .150 & .016 & .085 & .933 & .070 & 14.359 \\
\hline & Risk Management & .040 & .145 & .056 & .276 & .783 & .062 & 16.159 \\
\hline & Budget Support & .058 & .152 & .082 & .381 & .705 & .055 & 18.254 \\
\hline & Users Involvement & .124 & .154 & .190 & .802 & .426 & .045 & 22.097 \\
\hline & Project Progress Schedule & .056 & .151 & .090 & .369 & .714 & .043 & 23.321 \\
\hline & Team Capability & .088 & .123 & .122 & .720 & .474 & .089 & 11.219 \\
\hline & Right Team & .035 & .091 & .050 & .381 & .705 & .148 & 6.771 \\
\hline & Project Duration & .086 & .073 & .134 & 1.172 & .246 & .195 & 5.135 \\
\hline & Team Work & .042 & .111 & .062 & .382 & .703 & .096 & 10.377 \\
\hline
\end{tabular}

a. Dependent Variable: IT project Success

The coefficient of Table 2 shows the insignificance of all the variables in the study. This may lead to a conclusion that the above mentioned independent variables may not have sufficient impacts on the dependent variable. Due to this conclusion, the study has further moved to the collinearity diagnostic 
test which measures how much regressors are related to other regressors and how this affects the stability and variance of the regression estimates. To avoid such unwanted situation we run a stepwise regression. The stepwise regression will ignore all those independent variables which show some sort of relationship with each other and hence running regression model one by one. Given below are the results of stepwise regression.

\subsection{Analysis using stepwise regression methods}

Table 3 shows five regression models obtained through stepwise regression and each of the models show no co-linearity and high level of R-square.

Table 3

Model Summary

\begin{tabular}{ccccccc}
\hline Model & R & R Square & Adjusted R Square & Std. Error of the Estimate & F & Sig. \\
\hline 1 & $.718^{\mathrm{a}}$ & .515 & .509 & .3244 & 84.946 & $.000^{\mathrm{a}}$ \\
2 & $.844^{\mathrm{b}}$ & .713 & .705 & .2513 & 97.892 & $.000^{\mathrm{b}}$ \\
3 & $.872^{\mathrm{c}}$ & .761 & .752 & .2305 & 82.878 & $.000^{\mathrm{c}}$ \\
4 & $.896^{\mathrm{d}}$ & .803 & .793 & .2105 & 78.687 & $.000^{\mathrm{d}}$ \\
5 & $.905^{\mathrm{e}}$ & .819 & .807 & .2035 & 68.607 & $.000^{\mathrm{e}}$ \\
\hline
\end{tabular}

a. Predictors: (Constant), Project Progress Schedule

b. Predictors: (Constant), Project Progress Schedule, Training

c. Predictors: (Constant), Project Progress Schedule, Training, Budget Support

d. Predictors: (Constant), Project Progress Schedule, Training, Budget Support, Effective Communication

e. Predictors: (Constant), Project Progress Schedule, Training, Budget Support, Effective Communication, Right Team

The R-Square clearly indicated a higher level of explanation power for the proposed independent variables. Eq. (1) suggests $51 \%$ change by the independent variables while $71 \%$ in the 2 nd equation, $75 \%$ in the third, $79 \%$ in the fourth and $81 \%$ change forecasted by the 5 th equation respectively. Cumulative regression result shows significant indicating the rest of model but regression test significant values of all variables denoting rejection of hypothesis due to the insignificance $\mathrm{P}$ value of variables under study.

H1. Management support has an effect on IT projects success.

H2. The leadership has an effect on IT projects success.

H3. Effective monitoring and control have an average result on IT projects success.

H4. Clear goal powerfully has an effect on IT projects success.

H5. Requirement specification powerfully has an effect on IT projects success.

H6. Risk management has an average result on IT projects success.

H7. Budget support has an average result on IT projects success

H8. Customer/user involvement powerfully has an effect on IT projects success.

H9. Project Duration powerfully have an effect on IT projects success.

H10.Project progress schedule have a weak effect on IT projects success.

H11. Effective communication powerfully has an effect on IT projects success.

H12. Teamwork has an average result on IT projects success

H13. Team capability powerfully has an effect on IT projects success

H14. Select right team has an average result on IT projects success

H15. Training has an average result on IT projects success

Table 3 further shows the regression and residual values along with the value of F Statistics and suggests that all the five models are significant and valid. 
Table 4

Coefficients

\begin{tabular}{|c|c|c|c|c|c|c|c|c|}
\hline & \multirow[t]{2}{*}{ Model } & \multicolumn{2}{|c|}{$\begin{array}{l}\text { Unstandardized } \\
\text { Coefficients }\end{array}$} & \multirow{2}{*}{$\begin{array}{c}\begin{array}{c}\text { Standardized } \\
\text { Coefficients }\end{array} \\
\text { Beta }\end{array}$} & \multirow[t]{2}{*}{$\mathrm{t}$} & \multirow[t]{2}{*}{ Sig. } & \multicolumn{2}{|c|}{ Collinearity Statistics } \\
\hline & & $\mathrm{B}$ & Std. Error & & & & Tolerance & VIF \\
\hline \multirow[t]{2}{*}{1} & (Constant) & 2.635 & .198 & & 13.285 & .000 & & \\
\hline & Project Progress Schedule & .444 & .048 & .718 & 9.217 & .000 & 1.000 & 1.000 \\
\hline \multirow[t]{3}{*}{2} & (Constant) & 1.422 & .225 & & 6.315 & .000 & & \\
\hline & Project Progress Schedule & .338 & .040 & .547 & 8.455 & .000 & .871 & 1.148 \\
\hline & Training & .388 & .053 & .476 & 7.367 & .000 & .871 & 1.148 \\
\hline \multirow[t]{4}{*}{3} & (Constant) & 1.236 & .212 & & 5.833 & .000 & & \\
\hline & Project Progress Schedule & .268 & .041 & .433 & 6.573 & .000 & .707 & 1.415 \\
\hline & Training & .306 & .053 & .376 & 5.830 & .000 & .738 & 1.356 \\
\hline & Budget Support & .200 & .050 & .283 & 3.988 & .000 & 609 & 1.643 \\
\hline \multirow[t]{5}{*}{4} & (Constant) & 1.034 & .200 & & 5.180 & .000 & & \\
\hline & Project Progress Schedule & .214 & .039 & .346 & 5.427 & .000 & .628 & 1.592 \\
\hline & Training & .197 & .055 & .241 & 3.574 & .001 & .561 & 1.784 \\
\hline & Budget Support & .212 & .046 & .301 & 4.639 & .000 & .606 & 1.651 \\
\hline & Effective Communication & .196 & .048 & .269 & 4.068 & .000 & .584 & 1.714 \\
\hline \multirow[t]{6}{*}{5} & (Constant) & .944 & .196 & & 4.810 & .000 & & \\
\hline & Project Progress Schedule & .193 & .039 & .312 & 4.944 & .000 & .599 & 1.669 \\
\hline & Training & .171 & .054 & .209 & 3.144 & .002 & .540 & 1.852 \\
\hline & Budget Support & .192 & .045 & .272 & 4.255 & .000 & .585 & 1.709 \\
\hline & Effective Communication & .171 & .048 & .234 & 3.571 & .001 & .557 & 1.796 \\
\hline & Right Team & .111 & .044 & .160 & 2.523 & .014 & .596 & 1.677 \\
\hline
\end{tabular}

a. Dependent Variable: IT Project success

The coefficient of Table 4 shows the betas of all regressors in all 5 models. All of the independent variables are significant and explaining positively the dependent variables. All those variables which are insignificant and make the problem of multi-co-linearity are excluded from the analysis by the method itself. Hence, in given situation, model 5 is the holistic view of our proposed model and hence indicating that all the five independent variables are positively related with dependent variables and indicating a relationship.

\section{Conclusion}

The research results obtained clearly indicated that the Leadership Qualities played a significant role in obtaining Top Management support in order to access to resources however, the Leadership Qualities did not play any role on the trained and capable Project Team Members. Besides, it is undoubtedly defined effective communication of the project was established to be influential on the conclusion and contributing factor towards the Success of IT projects in Pakistan. Top Management Support as a whole was not found to play a key role in the IT Project Success. It has been pursued by the Leadership Qualities and experienced Project Team Members recognized by one of the most important factors towards the achievement of the IT Projects, it has been considered the second most important factor for IT Project Success.

The key intention of the research is to recognize the Critical Success Factors (CSF) to Information Technology. In this research, we discussed and listed the 15 CSF of IT projects which are critical for projects achievements. After reviewing different kinds of literature we looked for successful and unsuccessful references in IT project management. The data was gathered and we applied an investigated 
survey by taking interview on 80 specialist in IT and stakeholders. The outcome exposed the relationship between these factors which are Management support, leadership, Budget support, Right team, teamwork, effective communication, effective monitoring and controlling, requirement specification, project duration, a clear goal, Project progress schedule, team capability and risk management.

The exceptionality of this research is that we struggle to approach with a list of factors that are linked together in every Information Technology project not particularly to MIS or other software projects, etc. Our intention was to recognize and the important factors which have a high impact on project success in Information Technology.

After studying the PMbook 5 and literature regarding these factors gives an idea that the stakeholders throughout the project life cycle might not be surprised, there is nothing new for them and every point should be communicated and shared among them because communication gap strongly affects the project to success. It is the duty of every project team to stay in touch with everyone and project manager does follow ups for every activity. It is the responsibility of every responsible member of the project team to keep the interest and power of the stakeholders in view and then treat them accordingly

\subsection{Recommendations}

At project, start clarifying the requirements makes the project team focus on project goal and achievement which is highly motivated and successful. It is also the duty of project managers to prepare a communication plan to make sure the successful communication linking the project team members. For Future work, CSF recognized from the literature accepted to do interviews with IT firms to verify the existence of these variables. Through this, it will be found to get the better and clear perspectives of CSF to benefit the each and every organization of Pakistan to chase the successful implementation of IT projects.

For future, we also suggest that broad research is required in both qualitative and quantitative that will provide numerically. The hypothesis is deducted in this study. To prove the CSF observation is clear of the capacity of this paper. Investigators can numerically certify the hypothesis to prove their dependability and discover new CSFs. Some of the CSFs have more effect in influencing success on IT project. Either than suggested by our research but in previous studies, it could not be resolute due to different causes. Our research main aim was to focus on IT projects in government and non-government organizations of Pakistan limited to specific sector which is suggested in previous researchers in Pakistan but we also suggest that not only in specific sectors in Pakistan it should also be undertaken in other sectors as well as worldwide to find new CSFs for successful implementation and avoid failure of IT projects.

\section{References}

Amin, S. U., Kamal, Y., \& Sohail, A. (2016). The relationship between transformational leadership and project team performance: Assessing the mediating role of a project team management education. Apeejay Journal of Management Sciences and Technology, 3 (3), 1.12.

Anandarajan, M., Igbaria, M., \& Anakwe, U. (2002). IT acceptance in a Less-Developed country: A motivational factor perspective. International Journal of Information Management, 22(1), 47-65.

Bannerman, P. L. (2008). Risk and risk management in software projects: A reassessment. Journal of Systems and Software, 81(12), 2118-2133.

Berntsson-Svensson, R., \& Aurum, A. (2006). Successful software project and products: An empirical investigation. Paper presented at the Proceedings of the 2006 ACM/IEEE international symposium on Empirical software engineering.

Biehl, M. (2007). Success factors for implementing global information systems. Communications of the ACM, 50, 53-58. http://dx.doi.org/10.1145/1188913.1188917.

Bourne, L. (2002). What does a project manager need to deliver successful projects? DPM, RMIT, Reflective paper. 
Dolan, K. (2005). Critical Success Factors in Information Technology Project Management. Ph.D thesis submitted to Université de Montréal. Retrieve from http://hdl.handle.net/1866/1680.

Françoise, O., Bourgault, M., \& Pellerin, R. (2009). ERP implementation through critical success factors' management. Business Process Management Journal, 15(3), 371-394.

Imtiaz, A., Al-Mudhary, A. S., Mirhashemi, M. T., \& Ibrahim, R. (2013). Critical Success Factors of Information Technology Projects. World Academy of Science, Engineering and Technology, International Journal of Social, Behavioral, Educational, Economic, Business and Industrial Engineering, 7(12), 3154-3158.

Ingram, H., Biermann, K., Cannon, J., Neil, J., \& Waddle, C. (2000). Internalizing action learning: a company perspective. Establishing critical success factors for action learning courses. International Journal of Contemporary Hospitality Management, 12(2), 107-114.

Khilji, S. E. (2001). Human resource management in Pakistan, Human Resource Management in Developing Countries, Compiled by: Pawan S. Budhwar, Yaw A. Debrah, A Routledge Publication ISBN 0415343291,

Nasir, M. H. N., \& Sahibuddin, S. (2011). Critical success factors for software projects: A comparative study. Scientific Research and Essays, 6(10), 2174-2186.

Pastor, J., \& Casanovas, J. (2003). A goal/question/metric research proposal to monitor user involvement and participation in ERP implementation projects. Information Technology and Organizations: Trends, Issues, Challenges and Solutions conference, Philadelphia (USA), 325-327.

Somers, T. M., \& Nelson, K. G. (2004). A taxonomy of players and activities across the ERP project life cycle. Information \& Management, 41(3), 257-278.

Subba Rao, S. (2000). Enterprise resource planning: business needs and technologies. Industrial Management \& Data Systems, 100(2), 81-88.

Tesch, D., Kloppenborg, T. J., \& Frolick, M. N. (2007). IT project risk factors: the project management professionals perspective. Journal of Computer Information Systems, 47(4), 61-69.

Turner, J. R., \& Müller, R. (2005). The project manager's leadership style as a success factor on projects: A literature review. Project Management Journal, 36(2), 49-61.

Victor, O. I., Emeka, N. G., \& Chukwudi, N. (2014). Impact assessment of factors affecting information technology projects in rivers state, Nigeria. International Journal of Research in Engineering and Technology, 3(4), 757-764.

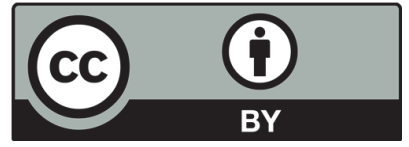

(C) 2017 by the authors; licensee Growing Science, Canada. This is an open access article distributed under the terms and conditions of the Creative Commons Attribution (CC-BY) license (http://creativecommons.org/licenses/by/4.0/). 